\title{
Polymorphisms in Intron 2 of Growth Hormone Gene and Their Associations with Economic Traits in Muscovy, Pekin, and Mulard Ducks
}

\author{
Asmaa W. Zaglool, Fardos A.M. Hassan ", Elshimaa M. Roushdy, Amir H. Abd-Elfatah
}

Department of Animal Wealth Development, Faculty of Veterinary Medicine, Zagazig University, El-Zeraa str. 114, 44511 Zagazig, Egypt

DOI: $10.36347 /$ sjavs.2020.v07i02.004

| Received: 12.02.2020 | Accepted: 18.02.2020 | Published: 27.02.2020

*Corresponding author: F.A.M. Hassan

\section{Abstract}

\section{Original Research Article}

This study aimed to determine the effects of genetic variability or polymorphisms in intron 2 of the $G H$ gene in three duck populations-Muscovy, Pekin, and Mulard. We employed PCR-RFLP to detect the various genotypes and studied their associations with important economic traits, such as body, dressing, breast, and thigh weights. Two alleles, $G H T$ and $G H C$, and three genotypes, $G H / T T, G H / C T$, and $G H / C C$, were identified in ducks at the locus, GH/BsmFI. In all duck populations, the frequency of allele $\mathrm{T}$ was higher than that of allele $\mathrm{C}$ and the most frequent genotype was GH/TT. All three genotypes were detected in Pekin ducks; whereas, only $G H / T T$ and $G H / C T$ genotypes were observed in Muscovy and Mulard ducks. Ducks with $G H / T T$ genotype was superior $(P<0.001)$ to birds with other genotypes with respect to the body, dressing, and breast muscle weights. Muscovy ducks with $G H / T T$ genotype had greater thigh weight $(P<0.001)$ than those with $G H / C T$ genotype. However, no significant difference was detected for thigh weight among the three genotypes in Pekin and Mulard ducks. Based on our study, we concluded that the $G H$ gene is an excellent genetic marker for enhancing the genetic potential of ducks for economically important traits.

Keywords: Ducks; economic traits; $G H$ gene, polymorphism; PCR-RFLP.

Copyright @ 2020: This is an open-access article distributed under the terms of the Creative Commons Attribution license which permits unrestricted use, distribution, and reproduction in any medium for non-commercial use (NonCommercial, or CC-BY-NC) provided the original author and source are credited.

\section{INTRODUCTION}

Growth rate and meat quality are two economically significant traits in ducks reared for meat. These are the primary concerns in breeding programs for determining their economical values $[1,2]$. This has subsequently spurred poultry scientists and producers to incorporate significant traits during selection in breeding programs to increase growth rates. The candidate gene approach stands out among the most imperative techniques to recognize DNA markers associated with economically important traits in farm animals [3]. Once a DNA polymorphism is associated with an important trait, the DNA marker could be used in the molecular MAS [4]. Several genes have been used as candidates for detecting polymorphisms related to productive and reproductive performances in animals; one of these is the growth hormone $(G H)$ gene [5].
Growth hormone $(\mathrm{GH})$ is a polypeptide hormone, created and secreted by the somatotroph cells of the anterior lobe of the pituitary gland, in a circadian and pulsatile manner [6]. It is necessary for growth and development [7], bone composition [8], lactation [9], reproduction [10] as well as metabolism of carbohydrates, lipids and proteins [11, 12]. Besides, $G H$ has a crucial role in innate and acquired immune responses. It affects the activity of phagocytic cells, the proliferation of lymphoid cells, thymus growth, and thymulin excretion [13]. Recent studies indicated that $G H$ is involved in sexual differentiation, pubertal maturation, gonadal steroidogenesis, gametogenesis, and ovulation [14,15]. In birds, $G H$ is not only essential for growth but is also embedded in a variety of secondary functions such as egg production, aging, and reproduction [16].

So far, the genomic structure of the $G H$ gene, which directly controls the synthesis of $G H$, has been studied in many species. The $G H$ gene is conserved in 
all the mammals as well as chicken, sharing a similar gene structure of five exons and four introns [17]. Furthermore, many polymorphisms have been identified in the GH genes of pigs [18, 19], bovines [20, 21], goats [22] and poultry [23-25]. Accordingly, the objectives of our study were to detect polymorphisms in the second intron of $c G H$ gene using the polymerase chain reaction-restriction fragment length polymorphism (PCR-RFLP) method and to analyze the associations of these polymorphisms with some economic traits in three duck populations-Muscovy, Pekin, and Mulard ducks.

\section{MATERIALS AND METHODS \\ Duck populations and phenotypic data}

One-day-old, male ducklings of Muscovy $(n=40)$, Pekin $(n=40)$ and Mulard $(n=40)$ breeds were obtained from a local, commercial hatchery and raised on floor pens with wood shavings as bedding, with a bird density of 5 ducks $\mathrm{m}^{-2}$. Each duck was fitted with a wing band. During the trial, the environmental temperature was maintained at $23 \pm 2.5^{\circ} \mathrm{C}$, and the light was provided continuously. From 1 st to 4 th weeks of age, the ducklings were fed with pelleted starter diets consisting of $22 \%$ crude protein (CP) and $12.12 \mathrm{MJ}$ of metabolizable energy. From 5th to 12 th weeks of age, they were fed with pelleted grower/finisher diets with $20 \% \mathrm{CP}$ and 12.56 MJ of metabolizable energy. Ducks had ad libitum access to food and water. The experimental protocol was in accordance with the regulations of the Local Experimental Animals Care Committee (ANWD 206) and approved by the institutional ethics committee. No mortality or morbidity was recorded during the study.

At the age of 12 weeks, body weights (BW) of live birds were measured, after $12 \mathrm{~h}$ with no access to feed. Their blood samples were harvested from the brachial vein into sterile vacutainer tubes containing the anticoagulant, EDTA, and then stored at $-20{ }^{\circ} \mathrm{C}$ until genomic DNA extraction. The birds were then euthanized by cervical dislocation, manually feathered, processed by removing the head, neck, shanks, and feet, and eviscerated. The dressed carcass, breast muscle, and thigh muscle were weighed and their percentages relative to live body weights were calculated.

\section{Genomic DNA extraction}

Genomic DNA was extracted from blood samples, using GeneJET whole blood genomic DNA purification mini kit (Thermo Fisher Scientific, Waltham, USA), following the manufacturers protocol. The quality and quantity of the resulting DNA from each sample was measured using agarose gel $(0.8 \%)$ electrophoresis and NanoDrop ${ }^{\circledR} 2000$ spectrophotometer (Thermo Scientific, Waltham, USA), respectively. Genomic DNA from each duck was stored at $-20{ }^{\circ} \mathrm{C}$ prior to the allelic discrimination assays.

\section{PCR amplification}

A fragment of $673 \mathrm{bp}$ covering intron 2 in $G H$ gene was amplified with the following sequences: F: $5^{\prime}$ GGAGGGCTAAGATCGTGCAT-3' and R:5'GCTTGTCCAGGGGAGACAAC-3' [2]. The qRTPCR was performed using $25 \mu \mathrm{L}$ reactions, containing 12.5 $\mu \mathrm{L}$ DreamTaq Green PCR Master Mix (Thermo Fisher Scientific, Waltham, USA), $2 \mu \mathrm{L}$ cDNA template, $1 \mu \mathrm{L}$ of each primer $(10 \mathrm{pmol} / \mu \mathrm{L})$, and $8.5 \mu \mathrm{L}$ deionized water. Following cycling conditions were applied: $5 \mathrm{~min}$ at $94{ }^{\circ} \mathrm{C}$, followed by 40 cycles of $20 \mathrm{~s}$ at $95{ }^{\circ} \mathrm{C}, 20 \mathrm{~s}$ at $60{ }^{\circ} \mathrm{C}$, and $30 \mathrm{~s}$ at $72{ }^{\circ} \mathrm{C}$, with a final extension of $5 \mathrm{~min}$ at $72{ }^{\circ} \mathrm{C}$. The amplified fragments were separated on $1.5 \%$ agarose gel electrophoresis and visualized in a gel documentation system under UV transilluminator (Bio-Doc Analyse, Biometra, Germany).

\section{PCR-RFLP analysis}

About $5 \mu \mathrm{L}$ of the PCR product was digested with 10 units of BsmFI restriction enzyme (Fermentas, Shenzhen, China) for $4 \mathrm{~h}$ at $65^{\circ} \mathrm{C}$. The digested fragment was identified by electrophoresis using $1.5 \%$ agarose gel, stained with ethidium bromide, and visualized in a gel documentation system under UV light. Genotypes were identified against the molecular marker, O'GeneRuler Low Range DNA ladder (Thermo Fisher Scientific, Waltham, USA).

\section{STATISTICAL ANALYSES}

All analyses were performed using SAS statistical system package v9.1 [26]. The allelic and genotypic frequencies were defined according to Falconer and Mackay [27], and Hardy-Weinberg equilibrium was explored by the chi-square test. Marker $\neg$ trait association analysis was conducted using t-test procedures in Muscovy and Mulard ducks and GLM procedures in Pekin ducks. The model used for data analysis was as follows: $\mathrm{Yij}=\mu+\mathrm{Gi}+\mathrm{Dj}+$ eij

where, $\mathrm{Yij}=$ observation of the target trait, $\mu=$ overall mean, $\mathrm{Gi}=$ fixed effect of ith genotype $(G H / T T$, $G H / C T$, and $G H / C C), \mathrm{Dj}=$ fixed effect of jth duck population (Muscovy, Pekin, and Mulard), and eij = random residual error.

The values were presented as least square means \pm SE. Bonferroni test was used to determine significant differences between mean values in Muscovy ducks. The effects of allelic substitution and dominance were calculated. The genotypes, GH/TT, GH/CT, and $G H / C C$, were represented as 0,1 , and 2, respectively, for the allelic substitution effect, while they were indicated as 0,1 , and 0 , respectively, for the dominance effect. 


\section{RESULTS}

PCR-RFLP analysis and allelic and genotypic frequencies of $\mathbf{G H}$ gene intron 2

The amplified genomic DNA of the $G H$ gene produced a 673 bp fragment, covering intron 2 (Fig. 1).
Three different genotypes were detected as a result of the digestion of this fragment with the BsmFI restriction enzyme. The genotypes are designated as TT (uncut 673 bp), CT (673, 456, and 217 bp), and CC (456 and 217 bp) (Fig. 2).



Fig-1: Amplification of GH gene in the studied duck populations. M: 100 bp ladder

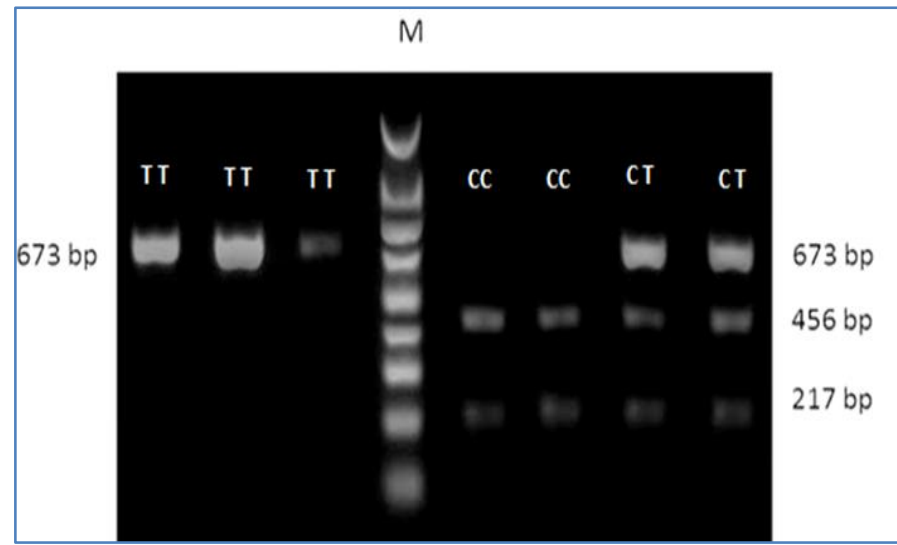

Fig-2: Restriction fragment patterns of GH gene after digesting with BsmFI. M: 100 bp ladder.

Table 1 lists the allele and genotype frequencies of the $G H$ gene intron 2 in the three duck populations. The results indicated that $G H T$ is the dominant allele, with frequencies of $0.91,0.71$, and 0.84 for Muscovy, Pekin, and Mulard ducks, respectively. Also, the most frequent genotype in all the examined ducks was $G H / T T$. Pekin ducks displayed the highest degree of genetic polymorphism for the duck
$G H$ gene intron 2. The genotype frequencies of the $G H / B s m F I$ locus in this duck population were not in Hardy-Weinberg equilibrium $(P=0.01)$. In contrast, only two genotypes- GH/TT and GH/CT-were detected in the Muscovy and Mulard ducks, with frequencies of 0.82 and 0.18 , and 0.67 and 0.33 , respectively.

Table-1: Genotypic and allelic frequencies of GH gene intron 2 in different duck populations

\begin{tabular}{|c|c|c|c|c|c|c|c|c|c|c|}
\hline \multirow[t]{3}{*}{ Population } & \multicolumn{6}{|c|}{ Genotype frequencies } & \multirow{2}{*}{\multicolumn{2}{|c|}{ Allele }} & \multirow{2}{*}{\multicolumn{2}{|c|}{ HWE }} \\
\hline & \multicolumn{3}{|c|}{ Observed } & \multicolumn{3}{|c|}{ Expected } & & & & \\
\hline & $\mathrm{GH} / \mathrm{TT}$ & $\mathrm{GH} / \mathrm{CT}$ & $\mathrm{GH} / \mathrm{CC}$ & GH/TT & $\mathrm{GH} / \mathrm{CT}$ & $\mathrm{GH} / \mathrm{CC}$ & $\mathrm{T}$ & $\mathrm{C}$ & $\mathrm{x}^{2}$ Calc & $P$-value \\
\hline Muscovy & $33(0.82)$ & $7(0.18)$ & $0(0.00)$ & $33.30(0.83)$ & $6.38(0.16)$ & $0.30(0.01)$ & 0.91 & 0.09 & 0.37 & 0.54 \\
\hline Pekin & $24(0.60)$ & $9(0.22)$ & $7(0.18)$ & $20.30(0.51)$ & $16.38(0.41)$ & $3.30(0.08)$ & 0.71 & 0.29 & 8.13 & 0.01 \\
\hline Mulard & $27(0.67)$ & $13(0.33)$ & $0(0.00)$ & $28.05(0.70)$ & $10.88(0.27)$ & $1.05(0.03)$ & 0.84 & 0.16 & 1.51 & 0.21 \\
\hline
\end{tabular}

Association of GH with selected economic traits

Table 2 summarizes the results of the GLM analysis of associations between the GH RFLP polymorphisms and selected economic traits in Muscovy ducks. The ducks with $G H / T T$ genotype were significantly $(P<0.001)$ heavier than those with the $G H / C T$ genotype, producing $843.5 \mathrm{~kg}$ more weight than the latter. The dressing, breast, and thigh weight percentages were higher in $G H / T T$ ducks than in 
Asmaa W. Zaglool et al., Sch J Agric Vet Sci, Feb, 2020; 7(2): 41-46

GH/CT ducks, by $3.47 \%, 2.06 \%$, and $1.41 \%$, respectively $(P<0.001)$.

Pekin ducks displayed a highly significant association $(P<0.001)$ among its different genotypes and the evaluated biometric traits (Table 3 ). The BW of $G H / T T$ ducks was $3592.4 \mathrm{~kg}$, which was higher than that of $G H / C T$ ducks by $520.1 \mathrm{~kg}$ and $G H / C C$ ducks by $699.3 \mathrm{~kg}$. There was no significant difference between GH/CT and $G H / C C$ ducks. Moreover, GH/TT genotype ducks had the highest dressing and breast weight percentages $(74.15 \%$ and $51.47 \%$, respectively) in comparison with the GH/TC ducks $(71.96 \%$ and $49.56 \%$, respectively) and the $G H / C C$ ducks $(70.19 \%$ and $48.13 \%$, respectively). No associations were observed among genotypes with respect to the thigh weight.

Mulard ducks also exhibited significant association $(P<0.001)$ between the different $G H$ genotypes and the biometric traits. The $\mathrm{BW}$ of $G H / T T$ ducks was notably higher than that of $G H / C T$ ducks by $332.8 \mathrm{~kg}$ (Table 4). The dressing and breast weight percentages of $G H / T T$ ducks were higher than that of $G H / T C$ ducks by $2.46 \%$ and $2.21 \%$, respectively. No significant difference was noticed among the three genotypes for thigh weight. Tables 2,3 , and 4 show the allelic substitution and dominance effects of different genotypes.

Table-2: Least squares means (SE) of selected economic traits in different genotypes of GH gene of Muscovy ducks

\begin{tabular}{|c|c|c|c|c|c|c|c|}
\hline \multirow[t]{2}{*}{ Traits } & \multicolumn{2}{|c|}{ Genotype } & \multirow{2}{*}{$\begin{array}{c}P \text { - } \\
\text { value }\end{array}$} & \multirow{2}{*}{$\begin{array}{c}\text { Additive gene } \\
\text { effect }\end{array}$} & \multirow{2}{*}{$\begin{array}{c}P- \\
\text { value }\end{array}$} & \multirow{2}{*}{$\begin{array}{c}\text { Dominance } \\
\text { effect }\end{array}$} & \multirow{2}{*}{$\begin{array}{c}P \text { - } \\
\text { value }\end{array}$} \\
\hline & $\mathrm{GH} / \mathrm{TT}$ & $\mathrm{GH} / \mathrm{CT}$ & & & & & \\
\hline $\begin{array}{l}\text { Body weight } \\
\text { (g) }\end{array}$ & $\begin{array}{c}4057.8 \\
(31.63)^{\mathrm{a}}\end{array}$ & $\begin{array}{c}3214.3 \\
(10.69)^{b}\end{array}$ & $<0.001$ & $-134.85(26.98)$ & 0.042 & $156.95(33.65)$ & 0.035 \\
\hline Dressing \% & $77.31(0.11)^{\mathrm{a}}$ & $73.84(0.07)^{b}$ & $<0.001$ & $-3.22(0.09)$ & 0.007 & $-3.75(0.13)$ & 0.001 \\
\hline Breast \% & $52.75(0.09)^{\mathrm{a}}$ & $50.69(0.15)^{b}$ & $<0.001$ & $-2.82(0.13)$ & 0.067 & $0.907(0.18)$ & 0.035 \\
\hline Thigh $\%$ & $24.58(0.07)^{\mathrm{a}}$ & $23.17(0.04)^{b}$ & $<0.001$ & $0.254(0.09)$ & 0.293 & $0.531(0.11)$ & 0.194 \\
\hline
\end{tabular}

SE: standard error.

Values within a row with different superscripts differ significantly.

Table-3: Least squares means (SE) of selected economic traits in different genotypes of GH gene of Pekin ducks

\begin{tabular}{|c|c|c|c|c|c|c|c|c|}
\hline \multirow[t]{2}{*}{ Traits } & \multicolumn{3}{|c|}{ Genotype } & \multirow{2}{*}{$\begin{array}{c}P \text { - } \\
\text { value }\end{array}$} & \multirow{2}{*}{$\begin{array}{c}\text { Additive gene } \\
\text { effect }\end{array}$} & \multirow{2}{*}{$\begin{array}{c}P \text { - } \\
\text { value }\end{array}$} & \multirow{2}{*}{$\begin{array}{c}\text { Dominance } \\
\text { effect }\end{array}$} & \multirow{2}{*}{$\begin{array}{c}P- \\
\text { value }\end{array}$} \\
\hline & GH/TT & GH/CT & GH/CC & & & & & \\
\hline $\begin{array}{l}\text { Body } \\
\text { weight (g) }\end{array}$ & $\begin{array}{c}3592.4 \\
(21.57)^{\mathrm{a}}\end{array}$ & $\begin{array}{c}3072.3 \\
(32.45)^{b}\end{array}$ & $\begin{array}{c}2893.1 \\
(17.65)^{b}\end{array}$ & $<0.001$ & $-115.69(29.14)$ & 0.051 & $129.95(21.27)$ & 0.039 \\
\hline Dressing \% & $\begin{array}{c}74.15 \\
(0.13)^{\mathrm{a}}\end{array}$ & $\begin{array}{c}71.96 \\
(0.08)^{b}\end{array}$ & $\begin{array}{c}70.19 \\
(0.11)^{\mathrm{c}}\end{array}$ & $<0.001$ & $-0.907(0.12)$ & 0.070 & $1.74(0.15)$ & 0.000 \\
\hline Breast \% & $\begin{array}{c}51.47 \\
(0.08)^{\mathrm{a}}\end{array}$ & $\begin{array}{c}49.56 \\
(0.16)^{b}\end{array}$ & $\begin{array}{c}48.13 \\
(0.04)^{\mathrm{c}}\end{array}$ & $<0.001$ & $1.16(0.08)$ & 0.198 & $1.10(0.11)$ & 0.224 \\
\hline Thigh $\%$ & $\begin{array}{l}22.64 \\
(0.20)\end{array}$ & $\begin{array}{l}22.29 \\
(0.31)\end{array}$ & $\begin{array}{l}22.05 \\
(0.21)\end{array}$ & 0.289 & $-0.539(0.25)$ & 0.728 & $-0.907(0.19)$ & 0.903 \\
\hline
\end{tabular}

Values within a row with different superscripts differ significantly.

Table-4: Least squares means (SE) of selected economic traits in different genotypes of GH gene of Mulard ducks

\begin{tabular}{|c|c|c|c|c|c|c|c|}
\hline \multirow[t]{2}{*}{ Traits } & \multicolumn{2}{|c|}{ Genotype } & \multirow{2}{*}{$\begin{array}{c}P \text { - } \\
\text { value }\end{array}$} & \multirow{2}{*}{$\begin{array}{c}\text { Additive gene } \\
\text { effect }\end{array}$} & \multirow{2}{*}{$\begin{array}{c}P \text { - } \\
\text { value }\end{array}$} & \multirow{2}{*}{$\begin{array}{c}\text { Dominance } \\
\text { effect }\end{array}$} & \multirow{2}{*}{$\begin{array}{c}P \text { - } \\
\text { value }\end{array}$} \\
\hline & GH/TT & GH/CT & & & & & \\
\hline $\begin{array}{l}\text { Body weight } \\
\text { (g) }\end{array}$ & $\begin{array}{c}3627.0 \\
(18.94)^{\mathrm{a}}\end{array}$ & $\begin{array}{c}3294.2 \\
(36.47)^{b}\end{array}$ & $<0.001$ & $-128.36(27.15)$ & 0.048 & $141.08(32.88)$ & 0.061 \\
\hline Dressing \% & $74.63(0.13)^{\mathrm{a}}$ & $72.17(0.11)^{b}$ & $<0.001$ & $-2.56(0.09)$ & 0.029 & $2.74(0.12)$ & 0.009 \\
\hline Breast \% & $51.39(0.08)^{\mathrm{a}}$ & $49.18(0.11)^{b}$ & $<0.001$ & $-1.25(0.07)$ & 0.147 & $-1.84(0.11)$ & 0.199 \\
\hline Thigh $\%$ & $23.22(0.15)$ & $22.98(0.21)$ & 0.124 & $-0.698(0.16)$ & 0.506 & $0.439(0.19)$ & 0.733 \\
\hline
\end{tabular}

SE: standard error.

Values within a row with different superscripts differ significantly.

\section{DISCUSSION}

Previous reports confirm that the exons and $5^{\prime}$ regulatory regions of the chicken $G H$ gene are highly conserved, and mutations predominantly occur in the introns [28-30]. Hence, the expression of $c G H$ may be regulated by the introns or the $3^{\prime}$ untranslated region. In the current study, we inspected the polymorphisms in intron 2 of the duck $G H$ gene. We identified three genotypes- $G H / T T, G H / C T$, and $G H / C C$ - using the PCR-RFLP technique, with the genotype $G H / T T$ being the most frequent. Pekin duck displayed the highest degree of genetic polymorphism, consisting of all the 
three genotypes; contrarily, Mulard and Muscovy ducks showed only two genotypes-GH/TT and GH/CT. These findings are supported by the results of Mazurowski et al. [31]. However, Wu et al. [2] reported that the $B s m F 1$ restriction enzyme enabled the detection of the three genotypes in all the populations of ducks. This disparity may be a result of the difference in breeds used in the experiments.

As a single polypeptide chain protein, the growth hormone $(\mathrm{GH})$ was formerly supposed to be participated only in the regulation of animal growth and development [32]. In the current study, we identified associations between the duck $G H$ genotypes and biometric traits of body, dressing, and breast muscle weights, which are of economic importance. We conclude that ducks with GH/TT genotype display higher values of these traits compared to ducks of other genetic groups. Considering that the GHT allele had a beneficial effect on growth and carcass traits, it would be favorable to select this allele during breeding to improve these economically important traits in ducks. Similarly, $\mathrm{Xu}$ et al. [32] reported that SNPs in intron 2 and 3 of $G H$ might impart some productive traits in duck. Mazurowski et al. [31] reported that Pekin and Mulard ducks with $G H / T T$ genotype were superior to birds with $G H / C T$ and $G H / C C$ genotypes with respect to body weight, length of the breastbone, and length of the shank. However, our findings regarding Muscovy ducks contrast with those published by Wu et al. [2]. They reported that Muscovy ducks with the genotype GH/CT were heavier birds than those with other genotypes.

\section{CONCLUSION}

PCR-RFLP is an extremely useful molecular technique that detects variations in gene loci. Our study revealed three different genotypes in duck $G H$ gene intron $2-G H / T T, G H / T C$, and $G H / C C$. We also observed strong associations between the polymorphisms in the duck $G H$ gene and various economic traits, including body, dressing, and breast weights. This indicated that the $G H$ gene might be a candidate marker for enhancing economic traits in ducks. Further studies are required with other loci in the same gene regions or other genes to develop the best selection methods, based on genes linked with production traits in ducks.

\section{Conflict of interest} of interest.

The authors declare that they have no conflict

\section{REFERENCES}

1. Sheng-Wai X, Wen-Bin B, Jun H, Jun-Hua C, Jing-Ting S, Gua-Hong C. Polymorphic analysis of intron 2 and 3 of growth hormone gene in duck. Hereditas. 2007; 29:438-442.

2. Wu Y, Pan AL, Pi JS, Pu YJ, Du JP, Liang ZH, Shen J. One novel SNP of growth hormone gene and its associations with growth and carcass traits in ducks. Molecular Biology Report. 2012; 39:8027-8033.

3. Rothschild MF, Soller M. Candidate gene analysis to detect genes controlling traits of economic importance in domestic livestock. Probe Newsl. Agric. Genomics. 1997; 8:13-20.

4. Gao Y, Zhang R, Hu X, Li N. Application of genomic technologies to the improvement of meat quality of farm animals. Meat Sci. 2007; 77:36-45.

5. Supakorn C, Pralomkarn W. Genetic polymorphisms of growth hormone $(\mathrm{GH})$, insulinlike growth factor1 (IGF-1) and diacylglycerol acyltransferase 2 (DGAT-2) genes and their effect on birth weight and weaning weight in goats. Philipp. Agric. Scientist. 2013; 96:18-25.

6. Ayuk J, Sheppard MC. Growth hormone and its disorders. Postgrad. Med. J. 2006; 82:24-30.

7. Ge X, Yu J, Jiang H. Growth hormone stimulates protein synthesis in bovine skeletal muscles cells without altering insulin-like growth factor-I mRNA expression. Journal of animal Science 2012; 90:1126-1133.

8. Ohlsson C, Bengtsson BA, Isaksson OG, Andreassen TT, Slootweg MC. Growth hormone and bone. Endocr. Rev. 1998; 19:55-79.

9. Baldi A. Manipulation of milk production and quality by use of somatotropin in dairy ruminants other than cow. Domest. Anim. Endocrinol. 1999; 17:131-137.

10. Scaramuzzi RJ, Murray JF, Downing JA, Campbell BK. The effects of exogenous growth hormone on follicular steroid secretion and ovulation rate in sheep. Domest. Anim. Endocrinol. 1999; 17:269277.

11. Davidson MB. Effect of growth hormone on carbohydrate and lipid metabolism. Endocr. Rev. 1987; 8:115-131.

12. Moller $\mathrm{N}$, Norrelund $\mathrm{H}$. The role of growth hormone in the regulation of protein metabolism with particular reference to conditions of fasting. Horm. Res. 2003; 59 (Suppl 1):62-68.

13. Gala RR. Prolactin and growth hormone in the regulation of the immune system. Exp. Biol. Med. 1991; 198:513-527.

14. Hull KL, Harvey S. Growth hormone: roles in female reproduction. J. Endocrinol. 2001; 168: 123.

15. Komisarek J, Michalak A, Walendowska A. The effects of polymorphisms in DGAT1, GH and GHR genes on reproduction and production traits in Jersey cows. Anim. Sci. Pap. Rep. 2011; 1:2936.

16. Kansaku N, Nakada A, Okabayashi H, Guéméné D, Kuhnlein U, Zadworny D, Shimada K. DNA polymorphism in the chicken growth hormone gene: Association with egg production. Anim. Sci. J. 2003; 74:243-244. 
17. Li J, Ran XQ, Wang JF. Identification and function of the growth hormone gene in Rongjiang pig of China. Acta PhysicaSinica 2006; 58:217-224.

18. Wenjun W, Lusheng H, Jun G, Nengshui D, Kefei C, Jun R, Ming L. Polymorphism of growth hormone gene in 12 pig breeds and its relationship with pig growth and carcass traits. Asian-Aust. J. Anim. Sci. 2003; 16:161-164.

19. Franco MM, Antunes RC, Silva HD, Goulart LR. Association of PIT, GH and GHRH polymorphisms with performance and carcass traits in Landrace pigs. J. Appl. Genet. 2005; 46:195-200.

20. Grochowska R, Srensen P, Zwierzchowski L, Snochowski M, Lovendahl P. Genetic variation in stimulated GH release and in IGF-I of young dairy cattle and their associations with the leucine/valine polymorphism in the GH gene. J. Anim. Sci. 2001; 79:450-476.

21. Yurnalis Y, Sarbaini S, Arnim A, Jarnsari A, Nellen W. Identification of single nucleotide polymorphism of growth hormone gene exon 4 and intron 4 in Pesisir cattle, local cattle breeds in West Sumatera Province of Indonesia. Afr. J. Biotechnol. 2013; 12: 249-252.

22. Malveiro E, Pereira M, Marques PX, Santos IC, Belo C, Renaville R, Cravador A. Polymorphisms at the five exons of the growth hormone gene in the Algarvia goat: possible association with milk traits. Small Rumin. Res. 2001; 41:163-170.

23. Zhang XL, Jiang X, Liu YP, Du H, Zhu Q. Identification of AvaI polymorphisms in the third intron of $\mathrm{GH}$ gene and their associations with abdominal fat in chickens. Poultry Science 2007; 86:1079-1083.
24. Ghelghachi AA, Seyedabadi H, Lak A. Association of growth hormone gene polymorphism with growth and fatness traits in Arian broilers. Int. J. Bio. Sci. 2013; 3:216-220.

25. Zhang Y, Zhu Z, Xu Q, Chen G. Association of polymorphisms of exon 2 of the growth hormone gene with production performance in Huoyan goose. Int. J. Mol. Sci. 2014; 15: 670-683.

26. SAS. SAS/STAT Users Guide. SAS Institute INC., Cary, NC 27513, USA, 2003.

27. Falconer DS, Mackay TF. Introduction to quantitative genetics, 4th ed. Longman Press, London, UK, 1996.

28. Li N, Zhang Y. Molecular cloning and analysis of growth hormone complementary DNA and 5' regulatory domain of growth hormone gene in chicken. Sci. Agric. Sin. 1996; 31:76-82.

29. Zhang Y, Li N. Molecular cloning and analysis of the partial 5' flanking regulatory region of chicken growth hormone gene. Acta. Genet. Sin. 1998; 25:427-432.

30. Stephen CY, Ip X, Zhang Q, Frederick CL. Genomic growth hormone gene polymorphisms in native Chinese chickens. Exp. Biol. Med. (Maywood) 2001; 226:458-462.

31. Mazurowski A, Frieske A, Kokoszynski D, Mroczkowski S, Bernacki Z, Wilkanowska A. Examination of growth hormone (GH) gene polymorphism and its association with body weight and selected body dimensions in ducks. Folia Biologica (Kraków). 2015; 63:43-50.

32. $\mathrm{Xu} \mathrm{SH}$, Bao WB, Cheng JH. Polymorphism analysis on coding and regulation regions of growth hormone gene in duck. Acta Vet. Zootech. Sin. 2007; 38:907- 912 . 